\title{
A keleti (mizrahi) zsidók letelepítése Izraelben Egy társadalmi leszakadás eredete
}

\author{
Resettlement of the Mizrahi Jews in Israel \\ The roots of social backwardness
}

\author{
GRÜNHUT ZOLTÁN
}

GRÜNHUT Zoltán: tudományos segédmunkatárs, MTA Közgazdaság- és Regionális Tudományi Kutatóközpont, Regionális Kutatások Intézete, Pécs; grunhut@rkk.hu

KULCSSZAVAK: Izrael, társadalmi törésvonalak, területi különbségek, településfejlesztés, gazdaságfejlesztés

ABSZTRAKT: A tanulmány célja kettős: egyfelől bemutatni az 1948 tavaszán függetlenséget nyert Izraeli Állam területére érkező zsidó menekülttömeg, köztük holokauszttúlélők és a muszlim országokat elhagyni kényszerülő tízezrek befogadásának, szociális, élelmezési és közegészségügyi ellátásának, oktatásának, valamint foglalkoztatásának nehézségeit, másfelől kidomborítani azokat a társadalmi és területi különbségeket, melyek a szervezett letelepítési programok, a tudatos társadalmi és gazdasági integrációs törekvések ellenére sem mérséklődtek, sőt stabilizálódtak.

A dolgozat első része számszerűsíti azt a hatalmas bevándorlási hullámot, amelynek eredményeként Izrael népessége alig több mint három esztendő alatt tulajdonképpen megduplázódott, majd ezt követően bemutatja a menekültek befogadásával járó kihívásokat, érzékeltetve azon társadalmi törésvonalakat, amelyek a korábban, cionista elhivatottságból érkezettek, illetve az újonnan, hontalanná vált nincstelenként betelepedők között kialakultak. Noha az állami intézményrendszer még csak formálódóban volt, a fenti nehézségek kezelése egyértelműen központi tervezést és végrehajtást követelt, amely kezdetben gyakorta kaotikusságot mutatott; az ötvenes évek derekára azonban alapos szervezettség vált jellemzővé, átfogó szociális, területi-települési és gazdasági programalkotással.

A tanulmány második fele ezen állami beavatkozássorozat következményeit tárja fel, hangsúlyozva a társadalmi és területi különbségek fennmaradásának eredendő okait, többek között a térbeli és szociális perifériára kerülés hatásait, az egyoldalú ipartelepítés problémáit, a delokalizáció kihívásait, továbbá a központosított településfejlesztés és politikai döntéshozatal hátrányait.

Zoltán GRÜNHUT: junior research fellow, Institute for Regional Studies, Centre for Economic and Regional Studies, Hungarian Academy of Sciences, Pécs; grunhut@rkk.hu

KEYWORDS: Israel, social conflicts, territorial disparities, regional development, economic development

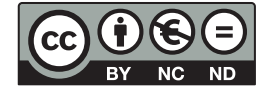


ABSTRACT: This article aims to present on the one hand the challenges the new-born State of Israel faced in 1948 (creating sustainable structures for housing, various social services, education, employment, food-security, healthcare, etc.) in addition to the absorption of Jewish refugees, including Holocaust survivors and tens of thousands of Jews from Muslim countries who had to leave their homes because anti-Zionist and anti-Semitic incidents became regular there, and on the other, to emphasise the social and territorial disparities which were not decreased, not even stabilised despite the comprehensive resettlement and economic programmes during the 1950s and 1960s launched by consecutive governments, as well as to point out the complex efforts for social integration.

The first part of the article presents the enormous immigration waves just after the establishment of the state in detailed numbers, during the Independence War (1948-49) and in the early fifties, when, in fact, the population of Israel had doubled. After the illustration of the basic demographic changes, the next part deals with the above mentioned challenges and with the social conflicts which emerged between the mainly Ashkenazi community (of European and American descent) - deeply Zionist-motivated, wealthier, better educated, socially more integrated, more influential in a political context - and the new-comer Sephardi (Mizrahi) immigrants from North Africa and the Middle East, much of them without any perspective and hopeless, at least disappointed.

Although the national institutions, their rights and powers, exact functions were undefined or non-existent at the time, just as the whole structure of public services and the central government had no financial resources available mainly because of having to defend the new-born state against the Arab invasions, it was clear that those serious difficulties needed comprehensive, state-organised solutions. The first actions of the central government were mostly stop-gap, ill prepared measures with chaotic practical implications. However, in the early fifties, well-planned, but lastly unsustainable regional and economic development programmes, as well as resettlement projects became typical which might - at most - have been suitable for a short transitional phase.

The second part of the article analyses the social and territorial consequences of these complex state-controlled interventions, the reasons behind the non-decreasing disparities, the negative impact of marginalisation on the Sephardic (Mizrahi) community, the problems created by the imbalanced industrialisation of Northern and Southern Israel, the challenges of uprooting and resettlement, as well as the drawbacks of the centralised spatial development, planning and governance structures.

\section{Az államalapítást követő zsidó bevándorlás tendenciái}

Már a Palesztina felosztásáról szóló 1947/181. ENSZ-határozatot követően is, de főként az állam formális megalakulása nyomán tömegessé vált a zsidók bevándorlása Izraelbe. A kormányzat kiemelt prioritásként kezelte a letelepítést, melyben együttműködő partnerként számíthatott a cionista szervezetekre, köztük is elsősorban a jelentősebb forrásokkal gazdálkodó és a diaszpóra egészében majdhogynem aktív Zsidó Ügynökségre (Shama, Iris 1977). David Ben Gurion ideiglenes, majd a tisztségben választások révén megerősített miniszterelnök merész kijelentést téve évi 150 ezer migráns befogadását tűzte ki célul, miközben a Zsidó Ügynökség legfeljebb 75 ezer ember letelepítését tartotta reálisnak (Hakohen 2003). A három esztendővel későbbi adatok aztán mindkét előzetes kalkulációnak ellentmondtak, ugyanis 1951 végéig majdnem 690 ezer bevándorló érkezett, s bár a következő évektől e szám jelentősen visszaesett, 1958-ig még így is további negyedmillió zsidó költözött Izraelbe (Eliav 1994). 
A betelepedetteknek két főbb csoportja különült el: egyfelől voltak a nyugati világból - Európából és az amerikai kontinensről - érkezők (döntően askenázi zsidók), másrészt az Észak-Afrikát és a Közel-Keletet hátrahagyók (szefárdok és mizrahi - keleti - zsidók). ${ }^{1}$ Mindkét közösség tagjai jórészt nincstelennek számítottak, hiszen az európai országokból beköltözők között főként holokauszttúlélők (kb. 130 ezer fó), brit menekülttáborokból kiszabadulók (kb. 30 ezer fó), valamint a szovjet befolyás alá kerülő Kelet-Európát sokszor vagyonelkobzás terhe mellett elhagyó menekültek (kb. 270 ezer fö) voltak, s csak alig 3-4\%-nyit (kb. 15 ezer főt) tett ki az Észak- és Dél-Amerikából bevándorló tehetősebbek aránya. Annak a nagyjából 490 ezernyi észak-afrikai és közel-keleti zsidónak, akik a hirtelen felszínre törő antiszemita lázongások miatt kényszerültek elhagyni otthonaikat, szintúgy nem maradt esélye pénzzé tenni ingatlanjait, földjeit s egyéb tulajdonait (Eliav 1994; Shulewitz 2000). Vagyis Izrael, melynek lakossága három esztendő alatt megduplázódott, egyszerre harcolt fennmaradásáért a háborús frontokon, s küzdött kilátástalan körülmények közepette a menekült százezrek letelepítéséért.

A sors sajátossága, hogy e majdnem reménytelen erőfeszítés kezelhetőbbnek bizonyult a függetlenségért való hadakozás idején, mint azt követően, mivel az 1948-49-ben érkezőket egyszerüen beköltöztették az elhagyott arab házakba, a háború miatti munkaerőhiány okán esély nyílt a megélhetésükre, s nem mellékesen a náci népirtás túlélőinek, valamint a brit táborokból kiszabadultaknak egyfajta pszichológiai elégtétel is volt a szabadságharcként értelmezett háborúban való részvétel. Tehát az említett lakhatási és gazdasági tényezők mellett ezen emocionális kontextus, valamint az, hogy 1948-49-ben többnyire európai bevándorlók érkeztek egy 85\%-ban európai származású közegbe, erős egységbe kovácsolta az izraeli lakosságot, a társadalmi összetartozás leküzdhetővé tette a belső és külső kihívásokat (Zameret 2002).

1949-50-től aztán megkezdődött a muszlim országokban élő zsidó közösségek szervezett bevándoroltatása, részben demográfiai okok, részben pedig a megsürüsödött antiszemita incidensek miatt (Levin 2001). A kormányzat - bár hivatalosan nem ismerte el soha - bevezetett egy ún. kiválasztási rendszert: azokból az országokból, ahol a zsidó népesség konkrét fizikai veszélynek volt kitéve, az egész közösséget megpróbálta átköltöztetni, míg a békés körülményü vagy legalábbis kevésbé konfliktusos államokból elsősorban a fiatal, családos, önellátásra képes aktív korúak bevándorlását támogatta. E politika jegyében a koldusszegény, üldöztetésnek kitett jemeni zsidókat (kb. 49 ezer embert) 1949 júniusa és 1950 szeptembere között ingajáratokkal Izraelbe szállították (ez volt a Csodaszőnyeg elnevezésű mentőakció), majd 1950-52 között két nagyobb, az Ezra és a Nehemija művelet keretében ugyanígy tettek az iraki zsidósággal (nagyjából 120-130 ezer emberrel) is (Ahroni 2001; Gat 1997). Mindeközben a marokkói közösség nem kapott korlátlan bevándorlási jogot, s a szétszakadt családok sokszor csak évek múltán egyesülhettek újra Izraelben (1. táblázat). 
1. táblázat: Zsidó bevándorlók Izraelben származási hely és év szerint Jewish immigrants in Israel by origin and year

\begin{tabular}{cccc|cccc}
\hline Év & $\begin{array}{c}\text { Európából, } \\
\text { Amerikából, } \\
\text { Óceániából }\end{array}$ & $\begin{array}{c}\text { Afrikából és } \\
\text { Ázsiából }\end{array}$ & $\begin{array}{c}\text { Összesen } \\
(f o ́)\end{array}$ & $\begin{array}{c}\text { Év } \\
\text { Amerikából, }\end{array}$ & $\begin{array}{c}\text { Európából, } \\
\text { Ózrikából és } \\
\text { Óceániából }\end{array}$ & $\begin{array}{c}\text { Összesen } \\
(f o ́)\end{array}$ \\
\hline 1949 & $52,7 \%$ & $47,3 \%$ & 239954 & 1958 & $55,5 \%$ & $44,5 \%$ & 27290 \\
1950 & $49,8 \%$ & $50,2 \%$ & 170563 & 1959 & $66,6 \%$ & $33,4 \%$ & 23988 \\
1951 & $28,1 \%$ & $71,9 \%$ & 175279 & 1960 & $70,8 \%$ & $29,2 \%$ & 24692 \\
1952 & $29,5 \%$ & $70,5 \%$ & 24610 & 1961 & $53,3 \%$ & $46,7 \%$ & 47735 \\
1953 & $27,5 \%$ & $72,5 \%$ & 11575 & 1962 & $22,9 \%$ & $77,1 \%$ & 61533 \\
1954 & $13,4 \%$ & $86,6 \%$ & 18491 & 1963 & $32,2 \%$ & $67,8 \%$ & 64489 \\
1955 & $8,6 \%$ & $91,4 \%$ & 37528 & 1964 & $59,1 \%$ & $40,9 \%$ & 55036 \\
1956 & $13,9 \%$ & $86,1 \%$ & 56330 & 1965 & $55,2 \%$ & $44,8 \%$ & 31115 \\
1957 & $57,9 \%$ & $42,1 \%$ & 72634 & 1966 & $60,8 \%$ & $39,2 \%$ & 15957 \\
\hline
\end{tabular}

Forrás: Statistical Abstract of Israel 2010 alapján.

\section{A tömeges bevándorlás következményei}

Az újonnan érkezők társadalmi és gazdasági integrálása komoly kihívásokat okozott. A kormányzat számára csupán rendkívül szűkös anyagi keretek álltak rendelkezésre, s a cionista szervezetek adománygyüjtésén kívül külföldi pénzforrásokra nemigen lehetett számítani (Ben-Porath 1986). Miközben az európai országok saját infrastruktúrájuk újjáépítésére koncentráltak, az Egyesült Államok pedig az ahhoz nyújtható kölcsönökre, Izraelnek egymagában kellett megoldania a háborús károk helyreállítását, a gazdasági szféra elhalt ágazatainak újraindítását, az 1948 előtti időszakban kialakult és jól működő, ugyanakkor a megnagyobbodott államterületre addig ki nem terjedő intézményi hálózat és közösségi szolgáltatói rendszer kiépítését, valamint a beáramló menekült százezrek letelepítését, s mindezt úgy, hogy közben az arab szomszédok fenyegetései miatt a fegyverkezés is szükségszerü prioritást élvezett (Gross 1995).

Jelentős fennakadások mutatkoztak az élelmiszerellátásban, mert bár a pionír falvak agrártevékenysége továbbra is példaértékủ maradt, az ország lakossága havonta tízezrekkel gyarapodott, így elkerülhetetlenül számottevő hiány keletkezett néhány alapélelmiszerben. A művelés alá vont arab földek megfelelő alapot biztosíthattak volna e szükséglet kielégítésére, ám az infrastrukturális elmaradottság (feltárt vízbázisok, csatornák, öntözőrendszerek, mezőgazdasági gépek és eszközök hiánya), valamint az elégtelen számú szakképzett munkaerő miatt alig-alig lehetett növelni a termésátlagokat. Gondot okozott az is, hogy az egyik legfőbb exportbevételi forrás - amelyre a pénztelenség miatt égető szükség volt - a citrusfélék világpiaci értékesítése volt, ám ezen, a lakossági élelemellátás szempontjából másodlagos ültetvények éppen a legtermékenyebb vidékeken voltak. Izrael tehát jelentős mennyiségű élelmiszerimportra kényszerült, főként gabonafélékből, hústermékekből, cukorból és konzervekből, miközben a kormányzatnak, illetve az alárendelt 
intézményi hálózatnak gondoskodnia kellett a behozatal társadalmi redisztribúciójáról is, hiszen a nincstelen bevándorló tömegek másként nem jutottak volna elegendő élelmiszerhez. A rendszer eredményes müködtetéséhez el kellett fojtani a burjánzó feketegazdaságot, rá kellett bírni a falvakat az alacsony árfolyamon rögzített állami felvásárlások tiszteletben tartására, egyúttal felügyelni kellett az önellátásra képesek szubvenciós struktúrán való kívül maradását (Kark 1995).

A tömeges bevándorlás az élelmiszerellátáshoz hasonlóan fajsúlyos problémákat generált a munkaerőpiacon is. Az arab világból érkezők többsége kiskereskedőként és kézművesként dolgozott korábbi hazájában, ám a kiűzetéssel elveszítették eszközeiket, kapcsolataikat, tőkéjüket, piacaikat, ráadásul a modern hébert sem beszélték. Olyasfajta szakképesítéssel (mérnök, építőipari, mezőgazdasági szakmunkás, orvos, ápoló), melyre az ötvenes évek eleji krízis idején kifejezett szüksége lett volna az államnak és a társadalomnak, nem rendelkeztek, ráadásul a tornyosuló kihívások közepette oktatásukra sem pénz, sem idő, sem elég szakember nem jutott. Emiatt legfeljebb segédmunkásként, valamint különböző agrár típusú idényfoglalkoztatásban tudtak elhelyezkedni (Rivlin 2010). A munkaerőpiacon való hirtelen, tömeges megjelenésükkel lenyomták az átlagkeresetet, bérfeszültségek keletkeztek az új és a korábban betelepedők között, ráadásul a foglalkoztatók a hatalmas kínálat miatt gyakorta visszaéltek helyzetükkel, amivel az államot (adókötelezettségek nem megfizetése) és a dolgozókat (jogsértések, túlóráztatás, kötelező juttatások megvonása) is megkárosították. Merthogy a muszlim világból bevándorló zsidó családok rendszerint igen népesek voltak, sok gyerekkel és időssel - vagyis eltartottakkal -, így e csekély jövedelemforrásból képtelenségnek bizonyult még a létminimumon való életvitel megteremtése is (Portugese 1998).

A kormányzat persze tisztában volt a körülményekkel, így kidolgozott és elindított egy több szempontból (lakásigény, munkanélküliség, infláció, élelmiszerhiány, infrastrukturális elmaradottság) sem halogatható közmunkaprogramot, ám annak anyagi eszközei, valamint szakmai humánerőforrással kapcsolatos előfeltételeit nem, illetve csak nagyon nehezen tudta biztosítani. A helyzetet súlyosbította, hogy az 1949-es fegyverszüneti egyezmények nyomán ezreket szereltek le a hadseregtől és a kisegítő egységek személyzetéből, akiket újra kellett integrálni a munkaerőpiacon. A volt katonák természetesen rendelkeztek nyelvismerettel, illetve a bevándorlókhoz képest általában magasabb iskolai-szakmai végzettséggel, ráadásul bizonyos politikai körök és a hadsereg prioritásként kezelte foglalkoztatásuk megoldását.

Egy következő aspektus, amelynek kapcsán égetően fontossá vált hatékony állami mechanizmusok intézményesítése, a népegészségügyi kihívás volt (Shvarts 2008). Az európai koncentrációs és haláltáborokból, valamint a brit menekültközpontokból kiszabaduló zsidók többsége fizikálisan legyengült állapotban, lelkileg összetörten érkezett Izraelbe. Sokukat néhány napnyi pihenést követően azonnal a hadszíntérre rendeltek, ezrek ugyanakkor folyamatos ápolásra szorultak. Már 1948-49-ben jelentős számú orvos és egyéb egészségügyi 
szakemberhiány mutatkozott, mely tendencia az ötvenes évektől még inkább nyomasztóvá vált. A folyamatosan növekvő népességgel nem tudott lépést tartani a kórházak, a betegágyak, a megfelelő müszerek, valamint a gyógyszertartalékok aránya. A muszlim világ zsidó üldözötteinek megérkezésével a népegészségügyi körülmények majdhogynem kilátástalanná váltak. A szegénysorban tengődött jemeni zsidók többsége a legalapvetőbb higiéniás feltételeket sem ismerte, sokuk lesoványodott fizikai állapotban volt, korábbi hazájában kevés és rossz minőségű élelmiszert fogyasztott. Az Irakból és Észak-Afrikából érkezők körében szintén jelentősnek bizonyult a különböző betegségekkel fertőzöttek aránya, ráadásul a hosszú hajóút, az összezártság ideje alatt az erősebbek is komolyan legyengültek. Mivel a bevándorlók elhelyezése átmenetileg - de gyakorta hónapokra, ha nem évekre - különféle, hosszas ott-tartózkodásra alkalmatlan tranzittáborokban történt, így a betegségek terjedése feltartóztathatatlanná vált, rendszeresen kialakultak kisebb járványok, szomorúan magas értékekre szökött a gyermekhalandóság. A problémák leküzdésére a kormány elrendelte, hogy egyes külföldi országokba (Jemenbe, Franciaországba, Marokkóba, Ciprusra) izraeli orvosok utazzanak ki, már ott helyben megkezdve a kezeléseket, az útra való fizikai felkészítést.

Lényeges kitérni a tömeges bevándorlás oktatáspolitikai hatásaira is. 1948 előtt a lakosság körülbelül 6,3\%-a nem tudott írni-olvasni, ám 1954-ig ez az arány $15 \%$ fölé emelkedett. A letelepedők többsége nem beszélt héberül, így a mindennapokban nyolc-tíz nyelv (orosz, angol, német, francia, jiddis, arab, ladino stb.) volt használatban. A bevándorló családokra jellemző igen magas gyerekszám miatt öt éven belül 300\%-kal növekedett az iskoláskorúak aránya, ami a tankötelezettség szükségszerű felemelésével még szignifikánsabb problémákat okozott. Mivel az arab országok főként az 1920-as és 1930-as évektől - eltéro” mélységü - kényszerszegregációban tartották zsidó közösségeiket, így az onnan Izraelbe érkező fiatalok csupán csekély hányada bírt szakképesítéssel, sőt egyáltalán az alapfokot - néhány tanulóévet - meghaladó iskolai végzettséggel. Az egészségügyi ellátáson túl a tranzittáborokban tehát gondoskodni kellett az oktatás megszervezéséről is, ám annak objektív feltételei - minden máshoz hasonlóan - hiányokat szenvedtek. Több nyelven beszélő tanárokra, a gyermekek és a munkába állásra váró felnőttek képzését biztosító tantervre, könyvekre volt szükség. Az aktív korúak esetében egyszerre kellett alapfokú és szakismereteket oktatni, gyakorlati jellegü tudást átadni, ráadásul az adott táborban rögtönzötten kialakított körülmények közepette, s nem intézményesült iskolai struktúrában (Iram, Shemida 1998).

Az államalapítást követően néhány esztendőn át tömeges formában zajló, de az ötvenes évek végéig kitartó bevándorlási hullám következtében az izraeli társadalom jelentősen átalakult (Bar-Jichak 2005). Az ország 1948 előtt alig 10\%ban afrikai-ázsiai származású népessége 1955-ig 40\% fölötti részarányra duzzadt, közösségi, gazdasági, politikai integrációja azonban nem történt meg. Az államvezetés, a közszolgálati bürokrácia és alkalmazotti kör, az értelmiség, valamint a tehetősebb vállalkozói réteg szinte kizárólag a korábban betelepedett 
európai-amerikai származásúakra épült. A kulturális törésvonalat tehát felerősítette egy sor társadalmi státuszkülönbség, amelyek elsősorban a jövedelemi és végzettségbeli differenciákból következtek. Mindezek hatására az izraeli társadalomban megindult egyfajta szétszakadás, elfojtott rivalizálás, mely mind a mai napig jelen van. Az ötvenes-hatvanas években a szegénysorból csak nehezen kitörni tudó mizrahi népességet sokszor kihasználták a politikai pártok is, amelyek később be nem tartott ígéretekkel igyekeztek tőkét kovácsolni a csüggedt, sorsukkal és kilátásaikkal elégedetlen, alárendelt státuszukba beletörődni nem akaró tízezrekből. Hogy lássuk, az állam mennyiben tudott hatékonyan fellépni e társadalmi törések összefoltozásában, s milyen - lehet, hogy elkerülhetetlen, de valós súlyukat tekintve mindenképpen későn felismert - hibákat követett el a keleti zsidó közösség letelepítése során, ahhoz vissza kell kanyarodnunk az első tranzittáborok felállításához.

\section{Az új bevándorló zsidók letelepítésének első fázisa}

Ahogyan az már szóba került, a bevándorlási hullám kezdeti időszakában főként az elhagyott arab ingatlanokba költöztették az érkezőket, mely lehetőség azonban gyorsan kimerült, egyfelől a migránsok magas száma, másrészt az üresen maradt házak nem megfelelö állaga, harmadrészt pedig az izraeli hadsereg preventív célú, az arab lakosság visszatelepülését ellehetetleníteni szándékozó rombolásai miatt (Morris 1989). Mire a harcok lezárultak, nem volt már több üres ingatlan, de ha lett is volna, a bevándorlók nem rendelkeztek elég megtakarítással a bérléshez, vásárláshoz, így mindenképpen központi intézkedéseket kellett elrendelni (Hill 1980). 1948-ban a kormány, a Zsidó Ügynökség és a Zsidó Nemzeti Alap közös erővel feltőkésített egy új intézményt, az ún. Amidárt, mely külföldi beruházók bevonása mellett megvalósítási tervet készített 16 ezer (egyenként 26 négyzetméteres) fa- és betonház felépítésére. Az új lakónegyedeket Izrael nagyobb városai mellett szándékoztak kialakítani, részben az infrastrukturális költségek mérséklése, részben a munkalehetőségek reális esélyü biztosítása végett (Cohen 1970). A kezdeményezés helyesnek bizonyult, csak éppen időben túlságosan is távlatinak ahhoz képest, hogy milyen arányban indult meg a zsidó menekültek áradata Európából és a muszlim országokból. Amint nyilvánvalóvá vált, hogy nincs esély valamennyi bevándorló lakhatását megoldani, a kormányzat átmeneti tranzittáborok felállítását rendelte el. Ezeket csupán ideiglenes, legfeljebb pár hétre szóló vészcselekvésnek szánta az államvezetés, a sátor- és viskóvárosok azonban évekig állva maradtak.

1950-ben építették az első sátortábort, melyhez hasonlók rövidesen az ország számos körzetében feltüntek, legnagyobb számban a parti síkságon. Egyegy ilyen tranzittáborban száz-kétszáz sátrat állítottak fel, körülbelül ugyanennyi család számára. Katonai elrendezés szerint tíz-húsz sátor volt egy sorban, 
illetve azokra jutott egy latrina és egy rögtönzött mosdóhely. A tábor közepén közösségi - oktatási, egészségügyi, élelmezési és adminisztrációs - célokat szolgáló nagyobb sátrakat, valamint zsinagógát húztak fel. A hónapok múlásával egy-egy táborban nemritkán családok ezrei is összezsúfolódtak, nyáron dülöngélve az árnyék nélküli hőségben, télen pedig vacogva a nyolc-tíz fokos hidegben. A szél, az esők és egyáltalán a mindennapos használat miatt gyorsan amortizálódtak a sátrak: gyakorta összerogytak, javíthatatlanná vált a fémvázuk, kiszakadt a szövetrészük. Amíg a táborokban élők jobb életkörülményekért tüntettek, addig az ideiglenes lakótelepekkel övezett városok népessége a betegségek terjedése, az olcsó munkaerő miatti elbocsátások, valamint a nélkülözők által elkövetett létszükség-bűncselekmények (főként lopások) okán elégedetlenkedett (Hakohen 2003). Habár az egyre konfliktusosabbá váló társadalmi helyzet súlyosságát a kormány idejében felismerte mind az életfeltételek tarthatatlansága, mind a slumosodás veszélye és a segélyen tengődés fenyegető tartóssá válása tekintetében, az anyagi források szükössége nem hagyott mozgásteret (Lipshitz 1998).

1950 májusában a kormány felállíttatta az első ideiglenes telepet (maabarát), mely eleinte még nem sokban különbözött a sátorvárosoktól a benne álló építmények jellegét tekintve, ugyanakkor a mindennapi életvitel szempontjából új struktúrák intézményesültek. A telepen külön ügyosztályi felügyelője volt a könnyüipari és halászati képzésnek, az agrárismeretek, a héber nyelv és az alapfokú tananyag oktatásának, a szociális és higiéniás jellegü intézkedéseknek, a vallásnak, valamint a nemek közötti egyenlőség megteremtésének (Shama, Iris 1977). Utóbbi azért is volt fontos, mert az izraeli társadalom férfi-női viselkedési és státuszbeli alapértékei igen távol álltak a muszlim környezetben kialakult hierarchikus formáktól. Az aktív korú lakosság eljárt a telepekről dolgozni, vagy olyan munkára, amelyet önmagától talált a környező városokban, falvakban, vagy időszakos jellegü állami közfoglalkozásokra (építkezésekre, betakarításokra). 1951-től a kormányzat már csak a sátraknál valamivel tartósabb, fakeretre húzott vászonkunyhók (badonim) építését engedélyezte a telepeken, majd újabb „előrelépésként” következett a külső vasvázas, fémtetejű s így a viharokkal szemben ellenállóbb, ám összességében szintén szövet-, pusztán pár helyszínen bádogborítású viskók (pahonim) időszaka, végül pedig az egyszerü szerkezetü faházak (crifonim) korszaka. Már 1952-t írtak, amikor megjelentek a később több éven át meghatározó, állami közmunkaprogram keretében épülő, lapos tetős, pár ablakos, eleinte csak kültéri, majd már saját fürdőszobával is rendelkező, általában húszegynéhány négyzetméteres, egymástól különálló betonházak (blokonim). Habár ez utóbbi építmények konstrukciós értelemben tartósak és jó beosztásúak voltak, a szegénysorban élő bevándorló népesség pénztelensége miatt általában rosszul felszereltek, ráadásul túlzsúfoltak maradtak (Eliav 1994). Amíg az izraeli átlag 2,2 fö/szoba volt, addig e betonházakban 2,6 feletti arány mutatkozott. A keleti zsidó családok jellemzően népes mivolta okán nemritkán hét fö vagy annál több élt egy fedél alatt. 
Miközben a nehéz sorsú bevándorlók örömmel fogadták az olcsó hitelekkel megvásárolható betonházak építését, nem értettek egyet azzal, hogy ilyen típusú beruházások szinte kizárólag a határvégeken és a periferikus körzetekben indultak. Nem akarták elhagyni az ország centrumtérségét, ahol mindig akadtak alkalmi munkák, s amely Izrael más vidékeihez képest messze kiemelkedett infrastrukturális és közszolgáltatási fejlettségével, valamint nemzetbiztonsági körülményeivel. 1950-ben hivatalossá vált az első nemzeti fejlesztési terv: összesen huszonnégy speciális körzetet alakítottak ki, azokban pedig számtalan mezőgazdasági kistelepülés, továbbá egy-egy nagyobb, közszolgáltatási, ipari, kereskedelmi és közlekedési centrumfunkciókat ellátó, ún. fejlesztési város felépítését irányozták elő (Tzfadia, Yiftachel 2004). Rögzítették továbbá azt is, hogy az ideális lakossági redisztribúció szerint legfeljebb a népesség 20\%-a élhet agrárfalvakban, míg 80\%-nak urbánus térségekben, nagyjából fele-fele arányban a három - izraeli léptékű - nagyközpontban (Tel-Avivban, Jeruzsálemben és Haifában), illetve különböző (20 és 50 ezer közötti) közép-, valamint (20 ezer alatti) kisvárosban kell otthonra találnia (Troen 1995).

\section{A fejlesztési városok társadalmi és területi hatásai}

A fejlesztési városok száma időről időre változott, így a szakirodalomban gyakorta eltérő adatok tűnnek fel. Ráadásul több település nem kapta meg a fejlesztési város státuszát, ám jellegét és időszakos speciális központi szubvencionálását tekintve tulajdonképpen annak minősült, ezért a hivatalos besorolás sem tekinthető teljesen iránymutatónak. Mivel a szakpolitika hangsúlyos alapelveként rögzítették, hogy az újonnan érkezők letelepítését a gyéren lakott déli és északi országrészekben kell megvalósítani, így a fejlesztési városok többsége - 80-85\%-a - e régiókban jött létre. A mára igen népessé lett, egykor volt fejlesztési városok, avagy ma is e státuszt viselő települések sorában említhetjük többek között Beer Sevát, Asdodot, Askelónt, Szderotot, Eilatot, Aradot, Kirjat Gatot, Dimonát, Kirjat Malakit, Micpe Ramont, Netivotot, Bet Seánt, Cfátot, Kirjat Smonát, Maalotot, Tiberiást, Afulát, Felső-Názáretet és Karmielt (1. ábra). A városok lakosságát fóként olyan bevándorlók adták, akik 1948 után érkeztek. Mialatt 1961-ben az össznépesség 45\%-át tette ki e migráns közösség, addig a fejlesztési városokban ugyanezen évben több mint kétharmados (67\%-os) hányadban éltek az államalapítást követően betelepülők (2. táblázat). Az Afrikából, Ázsiából és Európából származók közel sem azonos mértékben kerültek a fejlesztési városokba: miközben az Algériából, Marokkóból és Tunéziából elvándorolt zsidók nemzeti arányukhoz képest 2,48-szor nagyobb hányadban találtak otthonra e településeken, addig például a Németországot és Ausztriát hátrahagyók csupán 0,25-szörös arányban (Spilerman, Habib 1976). 
1. ábra: Fejlesztési városok Izraelben

Development towns in Israel

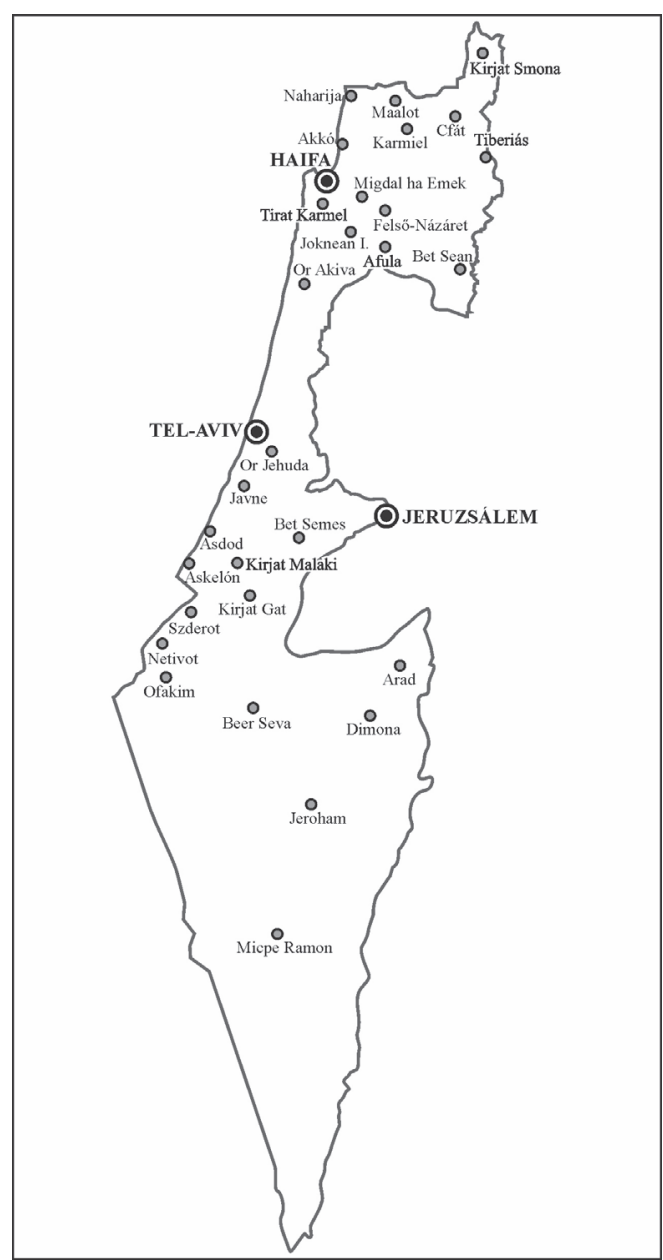

A lakossági redisztribúcióhoz hasonló eredményességgel haladt az előirányzott ipari széttelepítés, főként a könnyűipar (textil-, élelmiszer-, bőr- és cukoripar) vonatkozásában, de a Negevben bányászati és vegyipari központok is alakultak, miközben a tengerparti sávon (Asdodban és Askelónban) komoly kikötői fejlesztések történtek. A kifejezett kormányzati döntések mellett beruházásösztönző intézkedésekre is sor került, így például területi elven működő olcsó hitelek meghirdetésére, külföldi tőkeinjekciók jogszabályi elősegítésére, ingyenes szakképzésekre, családtámogatásokra, valamint regionálisan eltérő felvásárlói tömegárak megszabására. A központi tervezés ugyanakkor a legkevésbé sem segítette a települések iparszerkezeti diverzifikációját: a hatvanas évek végéig Dimonában a szekunder szféra dolgozói 96\%-ban, Kirjat Smonában 71\%-os 
2. táblázat: Demográfiai adatok néhány fejlesztési városban (1961)

Demographic characteristics of some development towns (1961)

\begin{tabular}{|c|c|c|c|c|c|c|c|c|c|c|}
\hline \multirow[t]{3}{*}{ Település } & \multirow{3}{*}{$\begin{array}{c}\text { Lakos } \\
\text { (1961), } \\
f^{\prime \prime}\end{array}$} & \multirow{3}{*}{$\begin{array}{c}\text { Izraeli } \\
\text { születésü, } \\
\%\end{array}$} & \multicolumn{3}{|c|}{$\begin{array}{l}\text { Külföldön született } \\
\text { (Mikor érkezett?) }\end{array}$} & \multicolumn{5}{|c|}{$\begin{array}{c}\text { Külföldön született } \\
\text { (Mely kontinensen, és mikor érkezett?) }\end{array}$} \\
\hline & & & \multirow{2}{*}{$\begin{array}{c}1955 \\
\text { után, } \\
\%\end{array}$} & \multirow{2}{*}{$\begin{array}{c}1948- \\
1954, \\
\%\end{array}$} & \multirow{2}{*}{$\begin{array}{c}1948 \\
\text { elött, } \\
\%\end{array}$} & \multicolumn{2}{|c|}{ Európa, Amerika } & \multicolumn{2}{|c|}{ Afrika, Ázsia } & \multirow{2}{*}{$\begin{array}{c}\text { Egyéb, } \\
\%\end{array}$} \\
\hline & & & & & & $\begin{array}{c}1948 \\
\text { után, } \\
\%\end{array}$ & $\begin{array}{c}1948 \\
\text { előtt, } \\
\%\end{array}$ & $\begin{array}{c}1948 \\
\text { után, } \\
\%\end{array}$ & $\begin{array}{c}1948 \\
\text { elött, } \\
\%\end{array}$ & \\
\hline Afula & 13844 & 35,7 & 28,7 & 59,6 & 11,7 & 50,7 & 10,2 & 32,3 & 0 & 6,8 \\
\hline Asdod & 4604 & 20,7 & 85,2 & 12,6 & 2,2 & 18,0 & 1,5 & 72,7 & 0,3 & 7,5 \\
\hline Askelón & 24510 & 34,1 & 28,4 & 67,2 & 4,4 & 27,5 & 3,6 & 64,4 & 0,3 & 4,1 \\
\hline Beer Seva & 45516 & 31,6 & 47,7 & 46,8 & 5,5 & 26,5 & 4,4 & 60,2 & 0,7 & 8,2 \\
\hline Bet Sean & 9719 & 29,6 & 55,9 & 43,1 & 1,0 & 13,5 & 0,7 & 82,1 & 0,2 & 3,5 \\
\hline Bet Semes & 6986 & 24,0 & 66,9 & 32,3 & 0,8 & 12,0 & 0,6 & 81,7 & 0,1 & 5,6 \\
\hline Dimona & 5000 & 23,7 & 86,5 & 11,7 & 1,8 & 12,9 & 1,3 & 78,1 & 0,3 & 7,4 \\
\hline Kirjat Gat & 10111 & 21,5 & 84,6 & 12,2 & 3,2 & 28,5 & 2,3 & 63,2 & 0,4 & 5,6 \\
\hline K. Malaki & 4544 & 28,6 & 55,9 & 43,3 & 0,8 & 4,6 & 0,8 & 90,1 & 0 & 4,5 \\
\hline K. Smona & 11796 & 27,8 & 60,4 & 37,5 & 2,1 & 17,8 & 1,6 & 71,8 & 0,4 & 8,4 \\
\hline Maalot & 1681 & 14,3 & 95,6 & 4,1 & 0,3 & 2,4 & 0,3 & 92,8 & 0 & 4,5 \\
\hline M. Ramon & 351 & 54,7 & 27,3 & 54,7 & 18,0 & 24,7 & 14,7 & 48,0 & 2,0 & 10,6 \\
\hline F-Názáret & 4291 & 12,7 & 87,9 & 7,6 & 4,5 & 83,3 & 3,8 & 7,5 & 0,4 & 5,0 \\
\hline Netivot & 2893 & 21,4 & 94,4 & 5,5 & 0,1 & 0 & 0,1 & 97,9 & 0,5 & 1,5 \\
\hline Ofakim & 4627 & 21,1 & 91,5 & 7,8 & 0,7 & 1,9 & 0,7 & 88,4 & 0,1 & 8,9 \\
\hline Or Akiva & 3208 & 21,0 & 51,9 & 47,7 & 0,4 & 26,6 & 0,2 & 67,3 & 0,1 & 5,7 \\
\hline Cfát & 10710 & 38,6 & 31,9 & 62,6 & 5,5 & 36,6 & 4,4 & 54,2 & 0,3 & 4,5 \\
\hline Szderot & 3539 & 26,1 & 81,2 & 18,2 & 0,6 & 4,3 & 0,3 & 90,9 & 0,3 & 4,2 \\
\hline T. Karmel & 10995 & 28,5 & 9,0 & 90,1 & 0,9 & 32,6 & 0,4 & 63,0 & 0,4 & 3,6 \\
\hline Joknean & 2854 & 35,4 & 7,3 & 81,1 & 11,6 & 29,3 & 9,5 & 54,2 & 0,6 & 6,4 \\
\hline Jeroham & 1574 & 18,4 & 72,2 & 26,9 & 0,9 & 12,3 & 0,5 & 57,5 & 0,5 & 29,2 \\
\hline Tiberias & 20792 & 49,3 & 24,7 & 66,9 & 8,4 & 15,6 & 4,4 & 72,4 & 2,8 & 4,8 \\
\hline
\end{tabular}

Forrás: Shama, Iris 1977, 66. alapján.

arányban, míg Afulában 57\%-os hányadban textilipari munkát folytattak. Askelónban az ipari foglalkoztatottak 46\%-a élelmiszer-feldolgozói állást töltött be, Jerohamban pedig 92\% bányász-, illetve kapcsolódó ágazati alkalmazott volt (Spilerman, Habib 1976).

A hetvenes évek elején kutatás készült, azt vizsgálva, kimutatható-e egyegy iparág, valamint az abban dolgozók körében szignifikáns különbség annak kapcsán, hogy a munkavállaló új bevándorlók mely országból származnak. Meglepően egyértelmű eredmények születtek: a jemeni zsidók részaránya a textiliparban háromszoros volt teljes lakossági hányadukhoz képest, a bányászatban a marokkói származásúak négyszeres, a cementgyártásban a líbiaiak szintén négyszeres, az algériaiak és a tunéziaiak pedig a faiparban képviseltek háromszoros részarányt. Ezzel szemben a jobban jövedelmező, magasabb szak- 
mai kvalitást igénylő, inkább a centrumtérségre koncentrálódó vegyiparban, gépés műszergyártásban, fémfeldolgozásban többnyire az Európából érkezők találtak megélhetést. A fejlesztési városokban kétségkívül nem a magas technológiájú ipari ágazatok jelentek meg, s igazából az egymást követő kormányzatoknak nem is volt kifejezett céljuk szorgalmazni ezt, mivel olyan termelőegységek kialakítására törekedtek, amelyek sok munkáskezet igényelnek és alacsonyabb kvalitású állománnyal is képesek eredményesen müködni (Razin 1996).

Noha a letelepítéssel kapcsolatos eredmények vitathatatlanok, az ideiglenes táborok hatvanas évek első harmadában történő felszámolása tény, a kormányzat által biztosított különböző programok pedig valóban hozzájárultak a felzárkózáshoz és az integrációhoz, ennek ellenére a fejlesztési körzetek kijelölése, valamint a fejlesztési városok építése, illetve az új bevándorlók szervezett odaköltöztetése bebetonozott bizonyos területi és társadalmi státuszkülönbségeket (Ben Ari, Bilu 1987; Lewis 1985; Peled 1990; Peled 1998). E folyamatot David Newman (2000) „kettős perifériára kerülésként” írta le, mondván a szegénysorban élő zsidó menekültek direkt módszerekkel való letelepítése az elmaradott térségekben jelentősen felerősítette a regionális és a társadalmi-gazdasági differenciákat. Mindmáig jellemző, hogy a déli és az északi országrészben a nemzeti átlaghoz képest magasabb a munkanélküliség, alacsonyabbak a jövedelmek, elavultabb az infrastruktúra s kevésbé képzett a lakosság. Newman szerint az izraeli esetben mégis az a rendkívüli - hiszen a világ legtöbb országában vannak fejlettségi különbségek -, hogy a zsidó államban nem feltétlenül a kormányzat tétlensége, hanem az ötvenes években mutatott aktivitása mélyítette egyes térségek és lakossági rétegek lemaradását. Ráadásul e feszültségeket kiélezte, hogy a társadalmi státuszok differenciálódása szubkulturális, tehát gazdagabb, iskolázottabb askenázik s szegényebb, képzetlenebb mizrahik, illetve etnikai, vagyis egyöntetűen tehetősebb és szélesebb perspektívákkal rendelkező zsidók, valamint minden tekintetben marginalizálódó arabok elkülönülésével párosult (Yiftachel 2001). Slomo Hasson (1998) e folyamatot - igen találóan - egyetlen mondatban úgy összegezte, hogy a fejlesztési városok, amelyek az Izraeli Állam megalakulását követően a telepítés- és területpolitika gerincét, a nemzetbiztonsági gondolkodás sarokpontját, valamint a központi tervezés egyértelmű prioritását alkották, a hatvanas évtizedre visszasorolódtak kiemelt státuszú „határkörzetből” felzárkóztatást igénylő „perifériákká”.

A fejlesztési városok leszakadásának van egy neomarxista magyarázata is, amely elsősorban azt emeli ki, hogy az ötvenes-hatvanas években e településeket az iparosodó Izrael egy-egy sarokkövének szánták, ugyanakkor a textil-, élelmiszer- és feldolgozóipar kialakítása mellett nehézipari beruházás alig történt. A hetvenes évtized végétől prioritást élvező, csúcstechnológiai ismereteket igénylő húzóágazatok (műszaki, katonai, elektronikai, orvostudományi kutatások) egyöntetűen a centrumkörzetre, a térség szakképzett humánbázisára és fejlett infrastruktúrájára koncentrálódtak, így a leszakadás felgyorsult. Mint azt e nézet képviselői nyomatékosítják, az állam nem „gondoskodóként”, a térbeli és társa- 
dalmi különbségeket csökkenteni igyekvő „fejlesztési redisztribútorként” lépett fel e válságos helyzetben, hanem „profitorientált kapitalistaként” (Tzfadia 2007).

Az Avraham Shama - Mark Iris szerzőpáros (1977) egy következő kritikai aspektust adva hangsúlyozta a fejlesztési városok központi tervezésének „személytelenségét", azt a hátrányos hozadékú sajátosságot, hogy e településeket pusztán „adatok” és „előrejelzések” alapján építették, figyelembe véve, hogy mennyi bevándorlót akarnak odatelepíteni, ehhez hány darab ingatlanra van szükség, azokhoz milyen alapinfrastruktúrát kell felépíteni, a beköltözők milyen típusú munkákat tudnak ellátni azonnal, s miféle gyorsképzésekkel lehet megalapozni a bizonyos fokú szaktudást igénylő ágazatok letelepítését. Nem volt tehát e településeknek szinte semmilyen organikus jellemvonása, mindent áthatott a mesterségesség, nemcsak a városi életterek kialakításában, de még az életvitel szervezésében is. Amiként a helyi gazdaság keretei központi tervezés alapján formálódtak, tekintettel a lokális természeti adottságokra és a nemzeti szükségletekre, de figyelmen kívül hagyva a betelepített aktív korú lakosság korábbi foglalkozási tapasztalatait, úgy a helyi politikát is „outsiderek” irányították. Évekig nem alakult ki városi elit, nem intézményesült a civil szektor, nem erősödött meg a helyi vállalkozói szféra, s mindezek okán nem jött létre valós települési közösség sem. Már a hatvanas években kimutathatóvá vált a fejlesztési városok képzettséget szerző, kisebb jövedelmet birtokló, a nyelvet jól beszélő és a társadalomba sikeresen beilleszkedett lakosai körében növekvő fokú elvándorlás a centrumkörzet felé, miközben a fejlesztési városok a saját térségükben fekvő kisfalvak lakosságát kezdték elszívni (Spilerman, Habib 1976).

A téma egyik jeles kutatója, Oren Yiftachel (1998) szerint az a metódus, ahogyan az 1948-49-es harcokat követően Izrael úgymond ,judaizálta”, zsidókkal benépesítette megnagyobbodott államterületét, valójában egy kolonizációs folyamatként értelmezendő. E „belső gyarmatosítás” keretében - nyomatékosítja a szerző - a politikai-gazdasági hatalmat kézbentartó askenázi zsidó közösség az új bevándorló, szükös anyagi erőforrásokkal bíró, iskolázatlanabb és nehezen integrálódó afrikai, ázsiai zsidókat a cionizmus magasztos céljai jegyében betelepítette az elüzött/elvándorolt arabok helyére, a periferikus körzetekbe. Yiftachel (1999 és 2006) szerint ennek nemcsak a területpolitika és a társadalmi kohézió tekintetében lettek súlyos következményei, de egyúttal Izrael államberendezkedésében is, amely már a kezdetek kezdetén alapvető jellege szerint ugyan demokratikus, ám az egyes közösségek státuszkülönbségei miatt inkább etnokratikus, etnikai hierarchiától terhes struktúrává torzult.

\section{Összegzés}

Háim Herzog volt izraeli köztársasági elnök az államalapítás után beáramló zsidó menekültáradatról úgy fogalmazott: „Ezeknek a betelepülőknek a befogadá- 
sa egy stabil, virágzó országnak is meghaladta volna a képességeit, elképzelhető, mekkora teher lehetett egy fiatal, önvédelemre kényszerített államnak. (...) Férfiak, nők, gyerekek százezrei zsúfolódtak össze a maabarának nevezett átmeneti táborokban. Senkinek sem volt magánélete, és a körülmények borzasztóak voltak. Létrehoztunk valami kezdetleges oktatási rendszert a gyerekeknek, de nyáron nagyon szenvedtek az iszonyú hőségtől és portól, télen viszont belesüppedtek a sárba. Volt idő, amikor egy szem gabona sem volt, és pénzünk sem, hogy kifizessük az Amerikából érkező szállítmányt." Herzog szerint David Ben Gurion, az állam első kormányfője volt „aki nemcsak összetartotta a küszködő nemzetet, hanem megoldást is talált e gyötrő problémákra. Miniszterelnökünk felszólítására [Jigáel] Jadín [vezérkari főnök] a hadsereget a tisztán katonai feladatokon túl közhasznú tevékenységek elvégzésével is megbízta. Például részt vállalt a mezőgazdasági ismeretek átadásában. Agrárprogramokat valósítottak meg, és a hadsereg maga is termelt gyümölcsöt és zöldséget az élelmiszerhiány enyhítése érdekében." (Herzogot idézi Gilbert 1998, 181.) E kríziskörülményekkel a fiatal nemzet alig több mint egy évtizeden belül - mondhatjuk - sikeresen megküzdött, ugyanakkor a menekültek szervezett letelepítése, munkához és megélhetéshez juttatása, társadalmi integrálása nagy árat követelt: olyan szociális és területi különbségek rögzülését, ami akkoriban még természetesnek hatott, manapság azonban már semmiképpen sem hagyható figyelmen kívül.

A mizrahi zsidóság jelentős megpróbáltatásai, beilleszkedésének nehézségei, illetve a közösség befogadása érdekében tett komplex lépések számtalan hibája sok szempontból tükröződik a mai Izraelen. Amit hat évtized alatt nem sikerült felszámolni, legfeljebb mérsékelni, azzal kapcsolatban nem is lehet reális elvárás, hogy a közeli jövőben érzékelhetetlenné válik. A mizrahi zsidóság leszakadásának tompítása állandó és összetett feladat, amelyet ráadásul komplikál, hogy a nyolcvanas évektől menekülthullámokban érkező etiópiai falasszák, valamint a következő évtizedtől tömegével, összességében a milliót is meghaladó számban bevándorló szovjet zsidók és hozzátartozóik letelepítése szintén nem zajlott problémamentesen, a társadalmi rétegződés tehát bonyolultabbá vált. $\mathrm{S}$ akkor még nem említettük Izrael közel 1,3 milliós kisebbségi népességét (a muszlim és keresztény arabokat, a sajátos szubkultúrát alkotó beduinokat, a drúzokat és a cserkeszeket) társadalmi, gazdasági, politikai és közösségi problémáikkal, valamint a 60-90 ezer főre tehető, jórészt illegálisan beszivárgó afrikai menekülteket, továbbá a szintén sok tízezer ázsiai és kelet-európai vendégmunkást. Miközben a mizrahik okkal és joggal beszélnek „elfeledett, jóvá nem tett igazságtalanságokról”, a mai Izrael társadalmi polarizálódásának tompítása már nem szűkíthető le az askenázi dominancia és a keleti zsidók alávetettségének orvoslására. 


\section{Köszönetnyilvánítás}

A kutatás a TÁMOP 4.2.4.A/2-11-1-2012-0001 azonosítószámú Nemzeti Kiválóság Program - Hazai hallgatói, illetve kutatói személyi támogatást biztosító rendszer kidolgozása és múködtetése országos program címủ kiemelt projekt keretében zajlott. A projekt az Európai Unió támogatásával, az Európai Szociális Alap társfinanszírozásával valósul meg.

\section{Jegyzet}

1 Noha a történelmi pontosság megköveteli, hogy elkülönítsük a 15. század végén az Ibériai-félszigetről kiűzött, s főként Észak-Afrikában, valamint Dél- és Délkelet-Európában letelepedő szefárd (spanyol) zsidókat a közel- és közép-keleti (mizrahi - keleti) zsidó közösségektől, az izraeli közbeszéd, s általában az izraeli szakirodalom is - talán hibásan - összemossa, s egységesen mizrahi zsidóknak nevezi e két csoport azon tagjait, akik a muszlim világból alijáztak. Jelen dolgozat a felhasznált - főként izraeli - szakirodalmakkal való könnyebb egyeztethetőség érdekében követi e terminológiát.

\section{Irodalom}

Ahroni, R. (2001): Jewish emigration from the Yemen, 1951-98: Carpet Without Magic. Curzon, Richmond Bar-Jichak, H. (2005): Israeli folk narratives: Settlement, immigration, ethnicity. Wayne State University Press, Detroit

Ben Ari, E., Bilu, J. (1987): Saints' sanctuaries in Israeli development towns: On a mechanism of urban transformation. Urban Anthropology and Studies of Cultural Systems and World Economic Development, 2., 243-272.

Ben-Porath, J. (1986): The entwined growth of population and product, 1922-1982. In: Ben-Porath, J. (ed.): The Israeli economy: Maturing through crises. Harvard Press, Boston, 27-41.

Cohen, E. (1970): Development towns: The social dynamics of "planted" urban communities in Israel. In: Eisenstadt, S. N., Bar Yosef, R., Adler, H. (eds.): Integration and development in Israel. Praeger, Jerusalem, 587-617.

Eliav, A. L. (1994): The absorption of one million immigrants by Israel in the 1950s. Refuge, 6., 11-15.

Gat, M. (1997): The Jewish exodus from Iraq, 1948-1951. Frank Cass, New York

Gilbert, M. (1998): Izrael története. Pannonica, Budapest

Gross, N. T. (1995): The economic regime during Israel's first decade. In: Troen, S. I., Lucas, N. (eds.): Israel: The first decade of independence. SUNY Press, Albany, 231-242.

Hakohen, D. (2003): Immigrants in turmoil: Mass immigration to Israel and its repercussions in the 1950s and after. Syracuse University Press, Syracuse

Hasson, S. (1998): From frontier to periphery. In: Yiftachel, O., Meir, A. (eds.): Ethnic frontiers and peripheries: Landscapes of development in inequality in Israel. Westview Press, New York, 115-141.

Hill, M. (1980): Urban and regional planning in Israel. In: Bilski, R., Galnoor, J., Inbar, D., Manor, J., Sheffer, G. (eds.): Can planning replace politics? The Israeli experience. Martinus Highoff, The Hague, 259-282.

Iram, J., Shemida, M. (1998): The educational system of Israel. Greenwood Press, Westport

Kark, R. (1995): Planning, housing and land policy 1948-1952: The formation of concepts and governmental frameworks. In: Troen, S. I., Lucas N. (eds.): Israel: The first decade of independence. SUNY Press, Albany, 461-494. 
Levin, I. (2001): Locked doors: The seizure of Jewish property in Arab countries. Praeger, Westport

Lewis, A. (1985): Phantom ethnicity: Oriental Jews in Israeli society. In: Weingrod, A. (ed.): Studies in Israeli ethnicity. After the ingathering. Routledge, London, 113-157.

Lipshitz, G. (1998): Country on the move: Migration to and within Israel, 1948-1995. Kluwer Academic Publishers, Dordrecht

Morris, B. (1989): The birth of the Palestinian refugee problem, 1947-1949. Cambridge University Press, Cambridge

Newman, D. (2000): Internal migration in Israel: From periphery to central - from rural to urban. In: Elazar, D. J., Weinfeld, M. (eds.): Still moving: Recent Jewish migration in comparative perspective. Transaction Books, New Brunswick, 205-227.

Peled, J. (1990): Ethnic exclusionism in the periphery: The case of oriental Jews in Israel's development towns. Ethnic and Racial Studies, 3., 345-367.

Peled, J. (1998): Mizrahi Jews and Palestinian Arabs: Exclusionist attitudes in a development town. In: Yiftachel, O., Meir, A. (eds.): Ethnic frontiers and peripheries: Landscapes of development and inequality in Israel. Westview Press, New York, 87-111.

Portugese, J. (1998): Fertility policy in Israel: The politics of religion, gender, and nation. Greenwood Press, Westport

Razin, E. (1996): Shifts in Israel's industrial geography. In: Gradus, J., Lipshitz, G. (eds.): The mosaic of Israel geography. Ben Gurion University, The Negev Center for Regional Development, Beer Sheva, 205-216.

Rivlin, P. (2010): The Israeli economy from the foundation of the state through the 21st century. Cambridge University Press, Cambridge

Shama, A., Iris, M. (1977): Immigration without integration: Third World Jews in Israel. Schenkman Publishing Company, Cambridge

Shulewitz, M. H. (2000): The forgotten millions: The modern Jewish exodus from Arab lands. Continuum, London

Shvarts, S. (2008): Health and Zionism: The Israeli health care system, 1948-1960. University of Rochester Press, Rochester

Spilerman, S., Habib, J. (1976): Development towns in Israel: The role of community in creating ethnic disparities in labor force characteristics. American Journal of Sociology, 4., 781-812.

Troen, S. I. (1995): New departures in Zionist planning: The development town. In: Troen, S. I., Lucas N. (eds.): Israel: The first decade of independence. SUNY Press, Albany, 441-460.

Tzfadia, E. (2007): Public policy and identity formation: The experience of Mizrahim in Israel's development towns. The Journal for the Study of Sephardic and Mizrahi Jewry, 1., 57-82.

Tzfadia, E., Yiftachel, O. (2004): Between urban and national: Political mobilization among Mizrahim in Israel's "development towns". Cities, 1., 41-55.

Yiftachel, O. (1998): Nation-building and the division of space: Ashkenazi domination in the Israeli 'ethnocracy'. Nationalism and Ethnic Politics, 3., 33-58.

Yiftachel, O. (1999): "Ethnocracy": The politics of judaizing Israel/Palestine. Constellations, 3., 364-390.

Yiftachel, O. (2001): The consequences of planning control: Mizrahi Jews in Israel's 'development towns'. In: Yiftachel, O., Little, J., Hedgcock, D., Alexander, I. (eds.): The power of planning: Spaces of control and transformation. Kluwer Academic Publishers, Dordrecht, 117-134.

Yiftachel, O. (2006): Ethnocracy: Land and identity politics in Israel/Palestine. University of Pennsylvania Press, Philadelphia

Zameret, Z. (2002): The melting pot in Israel: The commission of inquiry concerning education in the immigrant camps during the early years of the state. SUNY Press, Albany 


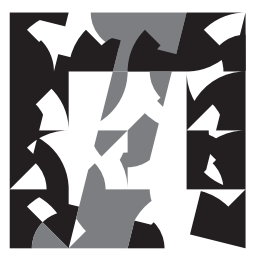

TÉR ÉS TÁRSADALOM | SPACE AND SOCIETY 